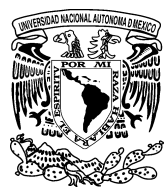

\title{
Market discipline in the Central American banking system
}

\author{
Disciplina de mercado en el sistema bancario centroamericano \\ Edgar Demetrio Tovar Garcia ${ }^{\mathrm{a}, \mathrm{b}}$ \\ a Universidad Panamericana, Mexico \\ ${ }^{\mathrm{b}}$ Universidad de Monterrey, Mexico
}

Received 20 November 2016; accepted 6 July 2017

Available online 27 November 2017

\begin{abstract}
The hypothesis of market discipline is empirically verified in the Central American banking system. A contrast is carried out on whether the riskier banks (the ones with the worst banking fundamentals) pay higher interest rates and receive smaller amounts in deposits. The generalized method of moments is used for dynamic panel data models (the SYS GMM estimator), as well as a sample of 30 banks from six Central American countries during the 2008-2012 period. Unlike the majority of the previous empirical literature, specifically for developed countries, no evidence of market discipline was found in Central America. The results are robust for several indicators of the banking fundamentals for purposes of internal demand of bank capital, and for other econometric models. These findings indicate weaknesses in the bank policy regarding the disclosure of information.

(C) 2017 Universidad Nacional Autónoma de México, Facultad de Contaduría y Administración. This is an open access article under the CC BY-NC-ND license (http://creativecommons.org/licenses/by-nc-nd/4.0/).
\end{abstract}

JEL classification: E59; G21; G39

Keywords: Market discipline; Internal capital market; Deposit market; Bank risk; Central America

\section{Resumen}

Se verifica empíricamente la hipótesis de disciplina de mercado en el sistema bancario centroamericano. Se contrasta si los bancos más riesgosos (con peores fundamentales bancarios) pagan tasas de interés más altas y reciben menores cantidades de depósitos. Se utiliza el método general de momentos para modelos dinámicos con datos de panel (el estimador SYS GMM) y una muestra de 30 bancos de 6 países centroamericanos durante

E-mail address: demetrio.tovar@gmail.com

Peer Review under the responsibility of Universidad Nacional Autónoma de México. 
el periodo 2008-2012. A diferencia de la mayor parte de la literatura empírica previa, particularmente para países desarrollados, en Centroamérica no se encontró evidencia de disciplina de mercado. Los resultados son robustos a varios indicadores de los fundamentales bancarios, al efecto de la demanda interna de capital del banco y a otros métodos econométricos. Estos hallazgos indican debilidades en la política de revelación de información bancaria.

(C) 2017 Universidad Nacional Autónoma de México, Facultad de Contaduría y Administración. Este es un artículo Open Access bajo la licencia CC BY-NC-ND (http://creativecommons.org/licenses/by-nc-nd/4.0/).

Códigos JEL: E59; G21; G39

Palabras clave: Disciplina de mercado; Mercado interno de capital; Mercado de depósitos; Riesgo bancario; Centroamérica

\section{Introduction}

After the global financial crisis that started in the United States in 2007-2008, the Basel Committee on Banking Supervision re-evaluated its basic recommendations in 2010, giving rise to the Basel III accord. Criteria for bank stability were reformulated, continuing to be in line with the three pillars indicated in Basel II: minimum capital requirements, bank supervision, and market discipline (Ayadi, 2013; Martínez Castillo, 2007).

The third pillar proposes a bank policy on disclosure of information to decrease moral risks and adverse selection. Said policy, on the one hand, is expensive and cumbersome for banks, and on the other hand, beneficial for society, since it could favor the stability of the banking system (Basel Committee on Banking Supervision, 2006, 2011, 2014). Said information would be utilized by the economic agents, who would make better decisions and would discipline the banks that incur in excessive risks through market, prices and quantity mechanisms, all the while sending market signals to bank supervisors (Tovar-García, 2014).

Evidently, neither the market nor the supervisors were capable of foreseeing and preventing the last banking crises. Nevertheless, the third pillar is still a key factor in the recommendations of Basel, which currently seeks to improve the comparability and consistency of the information to be released (Basel Committee on Banking Supervision, 2014). In this context, this research verifies the presence of market discipline in the Central American banking system. We contrast the hypothesis that states that the riskier banks pay higher interest rates and attract a smaller amount of deposits. The market discipline hypothesis has been positively verified mainly in developed countries (Berger \& Turk-Ariss, 2014), and there is also evidence of its presence in formerly socialist countries (Hasan, Jackowicz, Kowalewski, \& Kozłowski, 2013), in China (Wu \& Bowe, 2012) and in Latin America (Martinez-Peria \& Schmukler, 2001). In Central America, the hypothesis has been contrasted only in the case of Costa Rica, with weak evidence in support of it (Mayorga Martínez \& Muñoz Salas, 2002). Nonetheless, recent findings suggest that the previous empirical tests are biased, given that they do not consider the internal demand of capital by the banks (Ben-David, Palvia \& Spatt, 2013; Tovar-García, 2014).

This research utilizes accounting information (from the overall balance and the income statement) from 2008 to 2012 of 30 banks in Costa Rica, El Salvador, Guatemala, Honduras, Nicaragua and Panama. The study contributes to the literature in three ways. First, the hypothesis is reassessed in a new context, where the majority of the Central American countries have deposit insurance and are under the influence of the global financial crisis. Second, the generalized method of moments 
and a dynamic panel data model are used; the SYS GMM estimator (Blundell \& Bond, 1998) is used, which has been scarcely used to corroborate the presence of market discipline until now, but whose properties make it more attractive than the usual methods with fixed or flexible effects. Third, the domestic capital market effect is controlled, which goes largely ignored in previous literature.

Unlike most of the previous results, particularly in developed countries, the results found suggest the absence of discipline imposed by the depositors. These findings are robust for different specifications and methods. The main implication for the economic policy is the need to restore market discipline. The depositors must understand that they also play a role as watchmen of bank risk and those in charge of the economic policy must follow the recommendations of the Basel Committee on the bank policy regarding the disclosure of information, otherwise, the risk of a banking crisis increases.

The rest of the article develops in the following manner. Brief review of the literature briefly reviews the literature. Data and descriptive statistics section presents the main variables and the corresponding descriptive statistics. Econometric model and results section develops the econometric model, presents the estimations, and discusses the results. We finalize this article with a section for the conclusions.

\section{Brief review of the literature}

Market discipline in the banking system entails the reaction of the economic agents in the risk-taking of banks. Regarding bank liabilities, it is assumed that the depositors and other bank creditors find the excessive risk-taking by banks as a situation that elevates their costs, that is, it increases the risk that the bank might not be able to comply with its obligations. ${ }^{1}$ Therefore, the depositors (in the case of this research) will request a greater interest rate on their deposits and/or may withdraw their resources in response to the excessive risk-taking of their bank (DemirgüçKunt \& Huizinga, 2004). ${ }^{2}$

The foregoing is easily understood as the well-known offer and demand model. In the deposits market, the offer curve (depositors) will move to the left in response to the excessive risk-taking of the bank, arriving at a new balance point, which will have a higher interest rate and a smaller amount. Thus, the traditional market discipline tests verify two hypotheses:

H1. The riskier banks pay higher interest rates (market discipline mechanism through price).

H2. The riskier banks attract a smaller amount of deposits (market discipline mechanism though quantity).

The empirical tests consist in estimations of the offer curve of deposits based on the reduced form, given that the lack of data makes it impossible to simultaneously estimate offer and demand

\footnotetext{
1 The literature suggests that subordinated debt holders are the most interested in the monitoring of bank risk (TovarGarcía, 2015). Moreover, banks supervise the risk-taking of their colleagues in the interbank market (Tovar-García, 2016a, 2016b). Additionally, market discipline can also come from the side of bank assets, that is, borrowers are also interested in monitoring bank risk and they discipline banks because they prefer to request loans from banks that are well capitalized and with quality in their assets for refinancing and signaling purposes (Tovar-García \& Kozubekova, 2016). These hypotheses surpass the limits of this research; therefore, they are not verified for the Central American case.

2 The depositors can also modify the term of their deposits, preferring the short-term ones in response to the excessive risk-taking of the bank (Goday et al., 2005; Tovar-García, 2014). This third mechanism will not be verified due to lack of information.
} 
curves (Park, 1995; Tovar-García, 2014). Where the dependent variables are the interest rate and the growth rate of the deposits, and the main independent variable is the bank risk.

Market discipline assumes that the depositors are capable of understanding and monitoring bank risks. If this is not the case, it is due to a lack of transparency and banking information. Hence, the bank policy on disclosure of information proposed by Basel is important. Furthermore, it is assumed that the bank will also react, reducing its risks to avoid paying higher interest rates and to attract funds. It is in this last phase that market discipline becomes a reality (Flannery, 2001).

The two abovementioned hypotheses have been widely corroborated around the globe. Mainly, the empirical tests support the presence of market discipline in developed countries (Berger \& Turk-Ariss, 2014). Conversely, in developing countries, the evidence is contradictory or mixed.

In transition countries, such as Russia, empirical evidence suggests that the depositors monitor the risk-taking of their banks and primarily modify the deposited amounts. Russian depositors mainly respond to indicators of bank capitalization, liquidity and credit quality to decide the volume of their deposits. However, in Russia, the discipline mechanism through price (via the interest rate on the deposits) weakly responds to bank risk (Karas, Pyle, \& Schoors, 2010). In other countries of Central and East Europe the findings are similar, that is, the evidence in favor of the market discipline hypothesis is essentially found in the market discipline mechanism through quantity (Hasan et al., 2013). Therefore, it can be said that market discipline does exist in these countries. Perhaps, unlike other developing nations, it is in the transition countries that depositors are still wary of the capacity of the government to carry out bank bailouts. So is suggested by Russian banking and financial crisis in 1995 and 1998 (Karas et al., 2010). For example, in 2010, in Kyrgyzstan, it was impossible to bailout the largest bank in the country, thus the economic agents understand that there are banks that are too big to bailout and it is worth monitoring the risk-taking of banks, remaining mistrustful of government supervision (Tovar-García \& Kozubekova, 2016).

In emerging nations, such as China, the empirical results also suggest that the growth rate of the deposits reacts to the risk-taking of banks. Moreover, those banks with higher levels of transparency and banking information are capable of attracting more depositors (Wu \& Bowe, 2012). Conversely, in India, another one of the biggest emerging countries, there is no evidence in favor of the existence of market discipline. This brings forth the question of to what extent is the market capable of carrying out tasks of banking supervision, especially in nations with underdeveloped financial markets (Sarkar \& Bhole, 2009).

The evidence is also mixed in Latin America (see Tovar-García, 2014: Table 5, p. 24) and recent findings suggest a weak market discipline in the Mexican case (Tovar-García, 2014); contrarily to the positive evidence found by Martinez-Peria and Schmukler (2001) in the 1990s, and mainly after the Mexican crisis in 1994-1995.

It is interesting to acknowledge that the small depositors pay little attention to the risk indicators or banking fundamentals, they are guided by marketing, unlike the big depositors, who possess a great percentage of the total deposits, financial education, and resources to monitor their banks; as the Colombian evidence suggests (Márquez, 2011).

Furthermore, in developing countries, it is commonly argued that the market discipline tests through prices may be biased by the imperfect information that characterizes these markets and because it depends on the aversion to risk of the depositors (Mayorga Martínez \& Muñoz Salas, 2002; Park \& Peristiani, 1998; Park, 1995; Tovar-García, 2014). Consistently, there is strong evidence in Uruguay in favor of the market discipline hypothesis through the mechanism based on quantity, whereas there is weak evidence in favor of the price mechanism (Goday, Gruss, \& Ponce, 2005). In the Venezuelan case, favorable evidence is found only through the mechanism based on quantity (Muñoz, Cabeza, \& Guerra, 2013). 
Table 1

Sample of Central American banks.

\begin{tabular}{lcll}
\hline Country & Number of banks & Name of the banks \\
\hline Costa Rica & 2 & Banco Nacional de Costa Rica; Banco Lafise SA \\
El Salvador & 5 & & Banco Agricola; Scotiabank El Salvador SA; Banco Davivienda Salvadoreno, SA; \\
& Banco Citibank de El Salvador SA; Banco G\&T Continental El Salvador & Banco Industrial SA; Banco de Desarrollo Rural SA \\
Guatemala & 2 & Banco Financiera Centroamericana (FICENSA) \\
Honduras & 1 & Banco Citibank de Nicaragua SA \\
Nicaragua & 1 & Banistmo SA; Bancolombia (Panama) SA; Global Bank Corporation; Banesco S.A.; \\
Panama & 19 & Banco Bilbao Vizcaya Argentaria (Panama) SA; Banco Internacional de Costa Rica; \\
& & Credicorp Bank SA; GTC Bank Inc; Towerbank International Inc; Metrobank SA; \\
& Capital Bank Inc; Popular Bank Ltd Inc; BCT Bank International; MMG Bank \\
Corporation; Banco Universal S.A.; Banco Lafise Panamá, S.A.; BAC Bank Inc; & Banco Delta, S.A. (BMF); Banco Azteca (Panama) SA \\
& &
\end{tabular}

Source: Own elaboration.

In Central America, the market discipline hypothesis has been contrasted only for the case of Costa Rica. Mayorga Martínez and Muñoz Salas (2002) utilize monthly information from 21 banks in the 1995-2001 period to verify the market discipline hypothesis through quantity. ${ }^{3}$ Based on regressions with fixed effects, their results suggest a weak market discipline presence, where the banking fundamentals (main indicators of bank risk) and even macroeconomic variables do not seem to influence the behavior of deposits.

Recent findings for the United States reject the presence of market discipline when the tests control the effect of internal demand of bank capital, suggesting that the previous results are biased (Ben-David et al., n.d.). The market discipline tests assume that the interest rate (and the amount of deposits) are mainly determined by the offer. However, it is important to acknowledge that a higher interest rate can result in changes for the demand curve (on behalf of the bank), and this effect can be controlled utilizing the growth rate of the loans (Ben-David et al., n.d.; Tovar-García, 2014).

A higher interest rate on deposits could be the result of the displacement of the offer curve (as explained above), but it could also be the result of a displacement of the demand curve toward the right. If the bank faces a greater demand in loans (increase in the growth rate of the loans), in order to address it, higher interest rates can be paid to attract more deposits. Ben-David et al. (2013) find that bank capitalization (the main indicator of bank risk) does not determine the interest rate on deposits, which goes against the market discipline hypothesis. Conversely, the growth rate of the loans is the main determiner in favor of the internal demand of bank capital hypothesis.

\section{Data and descriptive statistics}

The bank data used in this research comes from the Bankscope agency, while the macroeconomic information was obtained from the World Bank (World Development Indicators - WDI). Currently, in the Central American countries being studied, there are 159 banks classified by Bankscope as commercial: 19 in Costa Rica, 14 in El Salvador, 24 in Guatemala, 19 in Honduras,

\footnotetext{
3 The lack of data made it impossible to verify the hypothesis through price.
} 
7 in Nicaragua, and 76 in Panama. However, several of the key indicators used in this investigation are not available for several of these banks, and after a revision and elimination of extreme values, the sample used herein includes 30 banks. Several of these banks are considered big in their respective countries, that is, they have a high percentage of participation in the different banking markets. A ranking of the banks can be found in Ríos (2012).

Nineteen banks (more than $60 \%$ of the sample) operate in Panama. There is no information of the best classified Panamanian banks, but there is information from several Panamanian banks that are positioned in the region between number 13 (Global Bank Corporation) and number 128 (Banco Azteca-Panama) out of 136 banks classified according to their size in 2011. There are data from five of the 14 banks that operate in El Salvador, three of which are the largest in the country. In Nicaragua, there is only complete information for Citibank (formerly Banco Uno) classified in the region as bank 91 at the end of 2011, at which time it was the fifth largest bank in the country but with a modest $5.8 \%$ of the credit portfolio. For the case of Honduras, we only have information on the Banco Financiera Centroamericana (FICENSA for its acronym in Spanish), classified in the region as bank 67, but it rates ninth in the country. In Costa Rica, we find information of one of the main state banks, Banco Nacional de Costa Rica, which is the largest bank in the country with $26.5 \%$ of the credit portfolio and positioned in the region as the fourth largest bank. The second Costa Rican bank in the sample is a foreign bank of Nicaraguan ownership, LAFISE, the tenth bank in the country and classified in the region as bank 73. Finally, in Guatemala, there is information of the Banco Industrial, classified in the region as the fifth largest and positioned as the first in the country with $26 \%$ of the credit portfolio. The second Guatemalan bank in the sample is a state bank, Banco de Desarrollo Rural, ${ }^{4}$ classified in the region as the eleventh largest and ranking the fourth largest in the country. See Table 1 and Ríos (2012). ${ }^{5}$

The years from 2008 to 2012 were analyzed because the banking information is more comprehensive for said period and because it comprises the effects of the global financial crisis; which although did not produce negative growth rates in all Central American countries, it did considerably reduce growth rates, mainly in 2009 . For this year, the corresponding rates are: $-3.1 \%$ for El Salvador, $-2.4 \%$ for Honduras, $-2.2 \%$ for Nicaragua, $-1.2 \%$ for Costa Rica, $0.5 \%$ for Guatemala and $3.8 \%$ for Panama.

There are two contrary positions regarding the effect that the banking and economic crises have on the market discipline of the banking sector. Martinez-Peria and Schmukler (2001) state that these favor market discipline, mainly after the crisis since they represent a call for depositors and other bank creditors to monitor bank risks. Conversely, recent findings suggest that banking crises weaken market discipline (Cubillas, Fonseca, \& González, 2012). We do not have sufficient data to corroborate the work hypothesis in pre-crisis, crisis and post-crisis periods. However, given that the global crisis originated in the United States, with strong effects on European countries and their banking systems, and with great media coverage, it is assumed that Central American depositors ought to be much more alert during the study period.

\footnotetext{
${ }^{4}$ It is important to note that there are few other state-owned banks in the sample, but it is not expected for these banks to bias the results of the research. Furthermore, the verification of the presence of market discipline for the entire banking sector and not only for private banking is of interest.

5 The sample is a limitation of the work and downplays the representativeness of the same. However, the analysis with panel data allows the analysis in time and space that favors the generalization of the results, taking the indicated limitations into consideration.
} 
Table 2

Descriptive statistics.

\begin{tabular}{llllll}
\hline Variable & Obs. & Mean & Standard deviation & Minimum & Maximum \\
\hline Total assets (a) & 150 & 2012610 & 2784982 & 24380 & $1.38 \mathrm{E}+07$ \\
Total deposits (a) & 150 & 1454333 & 1954988 & 10219 & $1.06 \mathrm{EE}+07$ \\
Interest rate on deposits & 150 & 3.4 & 2.0 & 0.4 & 19.9 \\
Deposit growth rate & 149 & 15.6 & 25.2 & -31.7 & 173.0 \\
Loan growth rate & 148 & 13.9 & 24.1 & -36.6 & 152.9 \\
Ratio of capital adequacy & 150 & 18.1 & 11.3 & 8.4 & 83.8 \\
Reserves for bad loans/total bad loans & 127 & 172.5 & 140.1 & 36.9 & 883.1 \\
Bad loans/total loans & 127 & 2.2 & 2.5 & 0.1 & 21.5 \\
ROA (net income/average total assets) & 150 & 1.5 & 1.3 & -1.6 & 8.0 \\
ROE (net income/average total shares) & 150 & 13.4 & 7.5 & -12.2 & 38.8 \\
Non-interest expenses/total income & 150 & 56.8 & 15.5 & 24.5 & 117.3 \\
Non-interest expenses/average assets & 145 & 4.3 & 6.4 & 0.7 & 41.9 \\
Liquid assets/deposits and short-term financing & 145 & 24.5 & 16.0 & 4.3 & 117.6 \\
Liquid assets/total deposits and loans & 124 & 22.4 & 17.0 & 4.3 & 117.6
\end{tabular}

Notes. This table presents the descriptive statistics of the banking variables. The sample includes 30 Central American banks and the period of study comprises the span of 2008-2012.

(a) Balance at the end of the year in thousands of dollars. The rest of the variables are percentage ratios.

Source: Own elaboration using information from Bankscope.

\section{Interest rate and deposit growth}

Given the limitations in obtaining direct information on interest rates paid by banks to the depositors, we utilize a common strategy seen in empirical literature. An implicit interest rate is used, calculated as the ratio between the interest expenses due to deposits and the total deposits (hereinafter, interest rate on deposits). This will be the dependent variable that will allow verifying the market discipline hypothesis based on a price mechanism. In the sample, the interest rate for average deposits is $3.4 \%$ and their standard deviation is $2 \%$ (see Table 2).

In developing countries, market discipline based on a market mechanism can be biased by imperfect information - as mentioned above-; therefore, it is important to verify the quantity based mechanism. For this purpose, the growth rate of the total deposits is expressed as a percentage, that is, current deposits over the deposits of the previous year. The average growth rate of the deposits is $15.6 \%$ and their standard deviation is $25.2 \%$ (see Table 2).

\section{Banking fundamentals: CAMUL classification system}

To verify the work hypothesis, the main independent variable is bank risk, which can be approximated utilizing the rates given by different credit rating firms. However, these firms assign ratings for a reduced number of Central American banks. Therefore, a common strategy in literature is used in this work, resorting to the banking fundamentals based on the CAMUL classification system (capitalization, asset quality, management, utilities and liquidity). ${ }^{6}$ The descriptive statistics of these variables are summarized in Table 2.

\footnotetext{
${ }^{6}$ CAMEL (capital adequacy, asset quality, management quality, earnings and liquidity).
} 
Table 3

Correlation matrix.

\begin{tabular}{|c|c|c|c|c|c|c|c|}
\hline & (1) & (2) & (3) & (4) & (5) & (6) & (7) \\
\hline Total assets (1) & 1.00 & & & & & & \\
\hline Total deposits (2) & 0.99 & 1.00 & & & & & \\
\hline Interest rate on deposits (3) & -0.26 & -0.25 & 1.00 & & & & \\
\hline Deposit growth rate (4) & -0.27 & -0.25 & 0.61 & 1.00 & & & \\
\hline Loan growth rate (5) & -0.20 & -0.17 & 0.15 & 0.54 & 1.00 & & \\
\hline Ratio of capital adequacy (6) & -0.22 & -0.22 & 0.00 & -0.01 & -0.25 & 1.00 & \\
\hline Reserves for bad loans/total of bad loans (7) & -0.15 & -0.13 & -0.08 & 0.16 & 0.37 & -0.10 & 1.00 \\
\hline Bad loans/total loans $(8)$ & -0.01 & -0.02 & -0.07 & -0.16 & -0.38 & 0.69 & -0.37 \\
\hline ROA net income/Average total assets (9) & -0.07 & -0.05 & -0.10 & -0.11 & -0.12 & 0.76 & 0.05 \\
\hline ROE net income/average total shares (10) & 0.06 & 0.09 & -0.14 & -0.13 & 0.12 & 0.02 & 0.30 \\
\hline Non-interest expenses/total income (11) & -0.08 & -0.09 & 0.20 & 0.35 & 0.18 & 0.09 & -0.08 \\
\hline Non-interest expenses/average assets (12) & -0.14 & -0.14 & 0.10 & 0.05 & -0.14 & 0.86 & -0.14 \\
\hline Liquid assets/deposits and short-term financing (13) & -0.20 & -0.22 & 0.07 & 0.18 & -0.01 & 0.80 & -0.01 \\
\hline \multirow[t]{2}{*}{ Liquid assets/total deposits and loans (14) } & -0.21 & -0.22 & 0.03 & 0.13 & -0.12 & 0.86 & -0.04 \\
\hline & $(8)$ & (9) & $(10)$ & $(11)$ & $(12)$ & $(13)$ & (14) \\
\hline Bad loans/total loans (8) & 1.00 & & & & & & \\
\hline ROA net income/average total assets (9) & 0.44 & 1.00 & & & & & \\
\hline ROE net income/average total shares (10) & -0.26 & 0.55 & 1.00 & & & & \\
\hline Non-interest expenses/total income (11) & 0.22 & -0.20 & -0.55 & 1.00 & & & \\
\hline Non-interest expenses/average assets (12) & 0.69 & 0.77 & 0.01 & 0.30 & 1.00 & & \\
\hline Liquid assets/deposits and short-term financing (13) & 0.61 & 0.59 & -0.05 & 0.25 & 0.77 & 1.00 & \\
\hline Liquid assets/total deposits and loans (14) & 0.65 & 0.65 & -0.03 & 0.23 & 0.80 & 0.99 & 1.00 \\
\hline
\end{tabular}

Notes. This table presents Pearson correlation coefficients between the main bank variables. The sample includes 40 Central American banks and the studied period comprises the span of 2008-2012.

Source: Own elaboration using information from Bankscope.

The bank capitalization level is approximated with the ratio of capital adequacy, that is, the basic capital (Tier 1) plus complementary capital (Tier 2), which ponders the capital with respect to the risk in assets according to the Basel rules.

The quality of the assets is measured with the ratio between bad recovery loans and the total of bad loans (defaulters). With a bigger ratio, a better security on the vulnerability of the base capital. The ratio is also used between bad loans and the total loans: a lower ratio corresponds to a greater quality in the assets.

The quality of the management is measured with two ratios. The first is between non-interest expenses and the total income; where usually the biggest portion of the expenses corresponds to salaries. This is a measure of efficiency, the lower the better. Similarly, the second ratio is between the non-interest expenses and the average of the assets.

The utility indicators are two typical ratios. First, the return on investment (ROA), which is maybe the most popular indicator on operational and efficiency performance. Second, the return on equity (ROE) on the share capital. The higher this figure is, the better, except in the case of high levels of leverage.

Finally, bank liquidity is approximated with the ratio of liquid assets on deposits and shortterm financing. It indicates the percentage in which the short-term financing can be covered in the event of sudden withdrawals. A higher percentage indicates better bank liquidity and lower vulnerability to banking panic. A second indicator is liquid assets on the total deposits and loans. 
Thus, there are two indicators for each of the CAMUL system categories, except for capitalization. It is no surprise to see the high correlation shown between each pair (see Table 3). Consequently, these variables are included to prevent multicollinearity in the econometric analysis, while making it possible to verify the robustness of the results for several indicators of the banking fundamentals.

\section{Econometric model and results}

It is important to note that there are endogeneity problems between the dependent and independent variables. To control double causality, as well as specification errors due to not including all factors that affect the interest rate and the growth of deposits, it is necessary to utilize instrumental variables. However, the lack of data makes it impossible to discover instruments. Due to these difficulties, Goday et al. (2005) and Tovar-García (2014) recommend utilizing the DIF GMM or SYS GMM estimators (Arellano \& Bond, 1991; Blundell \& Bond, 1998). These methods have been scarcely used to contrast the market discipline hypothesis.

Said estimators are based on the generalized method of moments (GMM) and utilize a dynamic panel data model, which allows controlling the autoregressive characteristics of the dependent variables, that is, the lags of the dependent variable as regressor are included. The DIF GMM method estimates an equation in first differences, utilizing the lag of the independent variables as instrumental variables. However, it was found that said estimation can be biased and result in weak instruments when the series are highly persistent, that is, series that are highly autoregressive (Blundell, Bond, \& Windmeijer, 2001). In that case, the recommendation is to utilize the SYS GMM method, which estimates an equation in levels and includes lag in first differences and lag in different levels of the independent variables as instruments. Nevertheless, in the case of small samples, the efficient GMM estimator in two stages can be biased, therefore, Windmeijer (2005) suggests a correction to the standard errors to obtain a more robust estimation. Subsequently, Bun and Windmeijer (2010) stress the advantages of the SYS GMM method over the DIF GMM method, which has led the former to be the preferred method in the majority of the researches applied in the last years. Furthermore, its use is recommended when the number of observations in time is fewer than the number of subjects in the sample, as it is in this case.

Thus, SYS GMM in two stages is the main method utilized in this research; the estimations of which will be consistent and unbiased if there is no autocorrelation-particularly of the second order-, and if the instruments are valid-for which the Sargan test is used. However, it is worth recognizing that the SYS GMM estimator can have weak instruments when the size of the sample is small, with relatively few temporary transversal cut observations (Bun \& Windmeijer, 2010).

The base model to contrast the market discipline hypothesis is given by Eq. (1):

$$
\begin{aligned}
& \text { Dependiente }_{i t}=\beta_{1} \text { Dependiente }_{i t-1}+\text { CAMUL }_{i t-1}^{\prime} \alpha+\beta_{2} \text { TAMAN } O_{i t-1} \\
& +\beta_{3} \text { Crecimientoprestamos }_{i t-1}+\text { MACRO }_{i t}^{\prime} \beta+\phi_{1} \text { SEGURO }_{i} \\
& +\phi_{2} \text { PANAMA }_{i}+T_{t}^{\prime} \tau+u_{i t}
\end{aligned}
$$

where Dependiente includes the interest rate on deposits and deposit growth rate variables to verify the market discipline hypothesis through price and quantity, respectively.

CAMUL includes the indicators for capitalization, asset quality, management, utility and liquidity (presented in the previous section), avoiding multicollinearity problems and allowing to verify the robustness of the results for different indicators of the banking fundamentals. Let us 
Table 4

Market discipline: price based mechanism.

\begin{tabular}{|c|c|c|c|c|c|c|c|c|}
\hline & \multirow{2}{*}{$\begin{array}{l}\text { Expected } \\
\text { sign }\end{array}$} & \multicolumn{7}{|c|}{ Dependent: Interest rate on deposits } \\
\hline & & $\begin{array}{l}\text { SYS } \\
\text { GMM } \\
\text { (1) }\end{array}$ & $\begin{array}{l}\text { SYS GMM } \\
\text { (2) }\end{array}$ & $\begin{array}{l}\text { SYS GMM } \\
\text { (3) }\end{array}$ & $\begin{array}{l}\text { SYS GMM } \\
\text { (4) }\end{array}$ & $\begin{array}{l}\text { DIF GMM } \\
\text { (5) }\end{array}$ & $\begin{array}{l}\text { Fixed } \\
\text { Effects } \\
\text { (6) }\end{array}$ & $\begin{array}{l}\text { Flexible Effects } \\
\text { (7) }\end{array}$ \\
\hline Lagged dependent & & $0.67^{* * * *}$ & $0.63^{* * * *}$ & $0.67^{* * * *}$ & $0.65^{* * *}$ & $0.67^{* * * *}$ & & \\
\hline Capital adequacy ratio & - & -0.01 & 0.02 & -0.04 & -0.002 & -0.03 & -0.04 & -0.02 \\
\hline Reserves for bad loans/total bad loans & - & -0.001 & & $-0.001^{*}$ & & $-0.001^{*}$ & -0.0003 & -0.0003 \\
\hline ROA & - & $-0.35^{* * *}$ & & $-0.40^{* * * *}$ & & $-0.39^{* *}$ & -0.31 & -0.20 \\
\hline Non-interest expenses/total income & + & 0.01 & & 0.01 & & 0.01 & 0.004 & 0.01 \\
\hline Liquid assets/deposits and short-term financing & - & -0.01 & & -0.02 & & -0.01 & 0.01 & 0.001 \\
\hline Bad loans/total loans & + & & 0.03 & & 0.04 & & & \\
\hline ROE & - & & $-0.03^{*}$ & & $-0.03^{*}$ & & & \\
\hline Non-interest expenses/average assets & + & & $-0.18^{* *}$ & & -0.14 & & & \\
\hline Liquid assets/total deposits and loans & - & & -0.03 & & -0.01 & & & \\
\hline Logarithm of the total assets (bank size) & & $0.17^{*}$ & $0.25^{* * * *}$ & $0.27^{* * * *}$ & $0.30^{* * * *}$ & 0.20 & -1.11 & $-0.57^{* * *}$ \\
\hline Loan growth rate & + & & & $-0.01^{*}$ & $-0.01^{* * *}$ & $-0.01^{*}$ & -0.01 & -0.01 \\
\hline GDP growth rate & & $-0.19^{* *}$ & $-0.18^{* *}$ & $-0.16^{* *}$ & -0.08 & $-0.15^{* *}$ & -0.04 & 0.03 \\
\hline Inflation & & -0.05 & $-0.09^{* *}$ & -0.05 & $-0.10^{* * *}$ & $-0.05^{*}$ & -0.07 & -0.12 \\
\hline $\begin{array}{l}\text { National interest rate } \\
\text { on deposits (median) }\end{array}$ & & 0.17 & 0.18 & 0.21 & 0.18 & 0.19 & 0.03 & $0.28^{* * * *}$ \\
\hline Deposit insurance (dummy) & & -0.03 & -2.05 & -1.78 & -2.35 & & & -0.29 \\
\hline Panama (dummy) & & -1.03 & 0.18 & -1.63 & -0.97 & & & 0.38 \\
\hline Year 2010 (dummy) & & 0.11 & -0.02 & -0.01 & -0.58 & -0.08 & $-0.86^{*}$ & $-0.98^{* *}$ \\
\hline Year 2011 (dummy) & & 0.76 & 0.70 & 0.63 & 0.01 & 0.51 & -0.83 & -0.95 \\
\hline Year 2012 (dummy) & & $0.99^{*}$ & $0.87^{*}$ & $0.95^{*}$ & 0.35 & 0.85 & -0.73 & -0.96 \\
\hline Period & & $2008-2012$ & & & & & & \\
\hline Observations & & 95 & 85 & 95 & 85 & 67 & 95 & 95 \\
\hline$N \times T$ & & $27 \times 4$ & $23 \times 4$ & $27 \times 4$ & $23 \times 4$ & $24 \times 3$ & $27 \times 4$ & $27 \times 4$ \\
\hline Sargan test (significance) & & $3.37(0.76)$ & $9.69(0.14)$ & $5.68(0.46)$ & $8.65(0.19)$ & $6.11(0.29)$ & & \\
\hline First order correlation test (significance) & & $-2.05(0.04)$ & $-2.08(0.04)$ & $-2.18(0.03)$ & $-2.22(0.03)$ & $-2.37(0.02)$ & & \\
\hline Second order correlation test (significance) & & $-0.10(0.92)$ & $-0.35(0.73)$ & $-0.32(0.75)$ & $-0.66(0.51)$ & $-0.41(0.68)$ & & \\
\hline
\end{tabular}

Notes. This table presents the results of the regressions using the SYS GMM estimator (Blundell \& Bond, 1998), in two stages. Similarly, results with the DIF GMM estimator (Arellano \& Bond, 1991) and regressions with fixed and flexible effects are presented. The independent variables (in the rows) enter with a lag and the dependent variable is the interest rate on deposits (read the regressions vertically). The sample includes annual observations from 2008 to 2012 from 30 Central American commercial banks. The bank data are taken from Bankscope and the macroeconomic variables are from the World Bank (WDI).

${ }^{*}$ Indicate statistical significance at $10 \%$.

${ }^{* *}$ Indicate statistical significance at $5 \%$.

*** Indicate statistical significance at $1 \%$ 
note that these variables are included with a bias due to the delay with which the information is received and processed by the depositors (additionally, it helps to control endogeneity).

The TAMANO $O$ variable is the logarithm of banking assets, a typical indicator of bank size that allows controlling this effect and the implicit policy of 'too large to go bankrupt'. There are no data to include other market power measures for each bank, which supposes that bank size is also a variable that allows controlling said power.

It is important to note that the model includes the Crecimientoprestamos variable (loan growth rate) to control the effect of the internal demand of bank capital (Ben-David et al., n.d.; TovarGarcía, 2014).

MACRO includes macroeconomic variables: GDP growth rate, inflation and the median of the interest rate on deposits (the source is WDI), ${ }^{7}$ thus the model controls the macroeconomic effects on the dependent variables for each country. SEGURO is a dichotomous (dummy) variable that takes the value of 1 if the country presents an explicit and limited insurance system for deposits, and the value of 0 in case of having an implicit deposit insurance, as is the case of Panama and Costa Rica. ${ }^{8}$ PANAMA is a dichotomous variable that takes values of 1 for the banks that operate in Panama and 0 otherwise. It is worth noting that the banks in Panama are the majority in the sample, and with this fictional variable, it is possible to control their effect and the general conclusions for Central America. ${ }^{9}$ Finally, $T$ is a dichotomous variable for the years of study, controlling market conditions that cannot be specified.

\section{Price based mechanism}

When the dependent variable is the interest rate on deposits, the statistical hypothesis indicates a negative relation to the banking fundamentals. That is, a negative relation to the capital adequacy ratio is expected, as well as reserves for bad loans/total bad loans, ROA, ROE, liquid assets/deposits and short-term financing, and liquid assets/total deposits and loans. Conversely, a positive relation with bad loans/total loans, non-interest expenses/total income, and non-interest expenses/average assets is expected.

Furthermore, a positive relation between the interest rate on deposits and the growth rate of loans is to be expected. This is interpreted in favor of the internal demand of capital hypothesis (Ben-David et al., n.d.). Several regressions are presented, including and excluding the loan growth rate to evaluate its impact on the interest rate and on the market discipline hypothesis (the effect of the banking fundamentals).

The main results are reported in Table 4 . The dynamic model is adequately justified. Note that the dependent variable as regressor presents statistical significance. The estimations with the SYS GMM (columns 1 to 4) do not present second order autocorrelation problems and the instruments are valid according to the Sargan test.

In general, the evidence in favor of the market discipline hypothesis through price is weak. Only the variables of return on assets and equities (ROA and ROE) present a statistical significance

\footnotetext{
7 A dollarization process was started in El Salvador since 2001, consequently, the bill rate of the United states was used as a macroeconomic control variable for this country.

${ }^{8}$ There are no indicators on other regulatory variables or on the institutional quality of each country. However, assuming that these institutional aspects change very little over time, the structure of the panel data allows controlling its possible impact.

${ }^{9}$ Due to multicollinearity problems (mainly with the macroeconomic variables), it is not possible to include dichotomous variables for other countries.
} 
Table 5

Market discipline: quantity based mechanism.

\begin{tabular}{|c|c|c|c|c|c|c|c|c|}
\hline & \multirow{2}{*}{$\begin{array}{l}\text { Expected } \\
\text { sign }\end{array}$} & \multicolumn{7}{|c|}{ Dependent: growth rate of the deposits } \\
\hline & & $\begin{array}{l}\text { SYS } \\
\text { GMM } \\
\text { (1) }\end{array}$ & $\begin{array}{l}\text { SYS GMM } \\
\text { (2) }\end{array}$ & $\begin{array}{l}\text { SYS GMM } \\
\text { (3) }\end{array}$ & $\begin{array}{l}\text { SYS GMM } \\
\text { (4) }\end{array}$ & $\begin{array}{l}\text { DIF GMM } \\
\text { (5) }\end{array}$ & $\begin{array}{l}\text { Fixed } \\
\text { Effects } \\
\text { (6) }\end{array}$ & $\begin{array}{l}\text { Flexible Effects } \\
\text { (7) }\end{array}$ \\
\hline Lagged dependent & & 0.17 & $0.15^{*}$ & 0.19 & $0.17^{*}$ & 0.19 & & \\
\hline Capital adequacy ratio & + & $-1.40^{* * *}$ & $-2.08^{* * * *}$ & $-1.58^{* * *}$ & $-2.20^{* * *}$ & $-1.60^{* * * *}$ & -1.04 & 0.02 \\
\hline Reserves for bad loans/total bad loans & + & $-0.03^{* *}$ & & $-0.02^{* *}$ & & $-0.02^{* * *}$ & -0.02 & -0.004 \\
\hline ROA & + & 2.82 & & $2.98^{*}$ & & $3.06^{*}$ & 2.41 & 3.20 \\
\hline Non-interest expenses/total income & - & -0.29 & & -0.25 & & -0.25 & 0.07 & $0.39^{* * * *}$ \\
\hline Liquid assets/deposits and short-term financing & + & -0.30 & & -0.32 & & -0.35 & 0.13 & $-0.39^{* *}$ \\
\hline Bad loans/total loans & - & & $3.76^{* * * * *}$ & & $3.86^{* * * *}$ & & & \\
\hline ROE & + & & -0.32 & & -0.28 & & & \\
\hline Non-interest expenses/average assets & - & & 0.69 & & 0.64 & & & \\
\hline Liquid assets/total deposits and loans & + & & -0.24 & & -0.24 & & & \\
\hline Logarithm of the total assets (bank size) & & $-57.2^{* * *}$ & $-48.9^{* * * *}$ & $-54.3^{* * *}$ & $-46.4^{* * * *}$ & $-52.8^{* * * *}$ & $-29.55^{* *}$ & $-5.57^{* * *}$ \\
\hline Loan growth rate & + & & & -0.12 & -0.05 & -0.13 & -0.05 & $0.23^{* * * *}$ \\
\hline GDP growth rate & & 0.20 & -0.43 & 0.43 & -0.67 & 0.18 & -3.61 & -0.80 \\
\hline Inflation & & 1.19 & 1.17 & 1.10 & 1.28 & 0.86 & -0.005 & -1.29 \\
\hline $\begin{array}{l}\text { National interest rate } \\
\text { on deposits (median) }\end{array}$ & & -0.86 & -1.52 & -0.43 & -2.41 & -0.63 & -5.48 & 0.35 \\
\hline Deposit insurance (dummy) & & $2148^{* * * *}$ & $1395^{* * * *}$ & $2113^{* * * *}$ & $1312^{* * *}$ & & & -10.67 \\
\hline Panama (dummy) & & $721^{* * * *}$ & $619^{* * * *}$ & $674^{* * * *}$ & $593^{* * *}$ & & & 3.50 \\
\hline Year 2010 (dummy) & & 1.06 & 0.98 & -0.85 & 0.60 & 0.26 & 11.49 & 6.81 \\
\hline Year 2011 (dummy) & & -1.04 & 0.33 & -3.27 & -0.27 & -0.93 & 16.22 & 9.22 \\
\hline Year 2012 (dummy) & & 6.72 & 9.67 & 5.24 & 9.26 & 7.05 & 16.34 & 4.50 \\
\hline Period & & 2008-2012 & & & & & & \\
\hline Observations & & 95 & 85 & 95 & 85 & 67 & 95 & 95 \\
\hline$N \times T$ & & $27 \times 4$ & $23 \times 4$ & $27 \times 4$ & $23 \times 4$ & $24 \times 3$ & $27 \times 4$ & $27 \times 4$ \\
\hline Sargan test (significance) & & $5.86(0.43)$ & $6.02(0.42)$ & $6.17(0.40)$ & $5.76(0.45)$ & $6.01(0.30)$ & & \\
\hline First order correlation test (significance) & & $-1.78(0.07)$ & $-1.58(0.11)$ & $-1.84(0.06)$ & $-1.69(0.09)$ & $-1.98(0.05)$ & & \\
\hline Second order correlation test (significance) & & $-0.58(0.56)$ & $-0.07(0.94)$ & $-0.56(0.57)$ & $-0.06(0.95)$ & $-0.56(0.57)$ & & \\
\hline
\end{tabular}

Notes. This table presents the results of the regressions using the SYS GMM estimator (Blundell \& Bond, 1998), in two stages. Similarly, results with the DIF GMM estimator (Arellano \& Bond, 1991) and regressions with fixed and flexible effects are presented. The independent variables (in the rows) enter with a lag and the dependent variable is the interest rate on deposits (read the regressions vertically). The sample includes annual observations from 2008 to 2012 from 30 Central American commercial banks. The bank data are taken from Bankscope and the macroeconomic variables are from the World Bank (WDI).

${ }^{*}$ indicate statistical significance at $10 \%$.

** indicate statistical significance at $5 \%$.

*** indicate statistical significance at $1 \%$ 
and the expected sign, that is, the banks with higher yields pay less for the deposits. The rest of the banking fundamentals do not show statistical significance or their effect lacks robustness by not presenting significance in most of the regressions.

It could be argued that the depositors mainly monitor the profitability of their bank as a key indicator for the decision making regarding the price at which to place their deposits, but it could also be possible that it is the low interest rate on deposits which facilitates the procurement of better yields for these banks. By not finding the expected relation with other banking fundamentals, the results suggest a weak presence of market discipline through price.

It is worth noting that the two first columns exclude the loan growth rate as an independent variable, (this is included in the regressions of columns 3 and 4), the effect of banking fundamentals on the interest rate on deposits is not affected. That is, only the ROA and ROE continue presenting the predicted effect on the market discipline hypothesis. Surprisingly, the loan growth rate presents statistical significance with the sign opposite to the one expected, contradicting the internal capital demand of the bank hypothesis. In other words, the banks that give out more loans pay less for deposits, and do not need to offer higher interest rates to attract deposits with which to meet the demand of loans. This implies that the credit activity of the bank depends on other funds and not on the deposits. However, the foregoing requires more sophisticated and focused proof, surpassing the limits of this research. ${ }^{10}$ Here, this variable is mainly included to control the effect of the banking fundamentals, which do not present relevant changes.

The bank size has a positive and robust effect on the interest rate on deposits (it is statistically significant in the four regressions). In other words, the largest banks pay higher interest rates for deposits, which implies the lack of an implicit policy of them being 'too large to go bankrupt'.

Among the macroeconomic variables, the GDP growth rate and the inflation present some significant and negative coefficients. Particularly, the growth of the GDP seems to negatively impact the interest rate on deposits. The dichotomous variables for the years of study do not present statistically significant effects in the majority of the regressions, with the exception of the year 2012, with a positive effect, suggesting the exit of the global crisis.

The dichotomous variable for the deposit insurance does not show a statistical significance, that is, having an explicit or implicit insurance (as in Costa Rica and Panama) does not affect the interest rates paid by the deposits.

\section{Quantity based mechanism}

When the dependent variable is the deposit growth rate, the statistical hypotheses indicate a positive relation with the banking fundamentals. This means that a positive relation with the capital adequacy ratio, reserves for bad loans/total bad loans, ROA, ROE, liquid assets/deposits and short-term financing, and liquid assets/total deposits and loans is expected. On the contrary, a negative relation with bad loans/total loans, non-interest expenses/total income, and non-interest expenses/average assets is expected.

Similarly, a positive relation between the deposit growth rate and the loan growth rate is expected, which is interpreted in favor of the internal demand of capital hypothesis.

The main results are reported in Table 5. The estimations with the SYS GMM (columns 1-4) do not present second order autocorrelation problems and the instruments are valid according to the Sargan test.

\footnotetext{
${ }^{10}$ Among the different tests carried out, it is worth mentioning that the deposit growth variable, when introduced without lag, presents a positive and significant effect in only one of the two regressions.
} 
Through the quantity based mechanism, the evidence is contrary to the market discipline hypothesis. Bank capitalization has a negative, significant, and robust effect on the growth rate of deposits, that is, the better capitalized banks obtain fewer deposits.

Furthermore, the quality indicators of the assets present a statistical significance and the opposite sign to the one expected. That is, the banks with a lower service quality obtain more deposits. It should be noted that the result is robust: the reserves for bad loans over the total of bad loans, and bad loans over total loans variables present evidence against the market discipline hypothesis in the three regressions, the last two (columns 3 and 4) include the loan growth rate as independent variable, which does not present a statistical significance and does not modify the effect of the banking fundamentals on the growth rate of the deposits. Consequently, there is also no evidence in favor of the internal demand of bank capital, unlike the case of the United States, where it determines the interest rates and the amount of deposits (Ben-David et al., n.d.).

The rest of the banking fundamentals do not present statistically significant or robust effects. The size of the bank, similarly to the mechanism based on the price, presents statistical significance and robustness, its effect on the deposit growth rate is negative, that is, the largest banks attract less deposits, supporting the previous finding against an implicit policy of a bank being too large to go bankrupt. Thus, the evidence contradicts the market discipline hypothesis, the depositors do not react in the expected manner to the banking fundamentals and to the size of the bank. Nevertheless, this last result must be treated with caution, as the sample includes mainly large banks in their respective countries.

The macroeconomic factors and the trend in time captured in the dichotomous variables for the years of study do not present statistically significant effects. On the other hand, the dichotomous variable for the banks that operate in Panama presents a positive and significant effect, that is, these banks show deposit growth rates that are greater to the rest of the Central American banks.

Unlike the price based mechanism, the dichotomous variable for deposit insurance presents statistical significance and a positive effect, that is, the deposit growth rates are greater in countries with an explicit and limited insurance scheme, implying that the deposit insurance provides depositors with a greater sense of confidence.

It is worth pointing out that the motivation behind the research by Mayorga Martínez and Muñoz Salas (2002) was the discussion on the integration of an explicit and limited deposit insurance for Costa Rica. On the one hand, the deposit insurance provides a certainty on the intervention of the state in case of bank failure and prevents banking panic. On the other hand, there is empirical evidence that suggests that deposit insurance weakens market discipline (DemirgüçKunt \& Huizinga, 2004; Sulamita Estrada, 2013). However, the results presented here suggest a weak presence of market discipline through price, and its total absence through quantities for the 2008-2012 period. Moreover, Mayorga Martínez and Muñoz Salas (2002) report a weak presence of market discipline through quantity for the 1995-2001 period. Consequently, the arguments against the inclusion of the deposit insurance due to it negatively affecting market discipline lack any sense, as there is no evidence of its presence.

In sum, there is no evidence of market discipline in the Central American banking system, these results coincide in good measure with those presented by Mayorga Martínez and Muñoz Salas (2002) for the Costa Rican case.

It should be noted that the regressions were also estimated using robust standard errors according to Windmeijer (2005). As is to be expected, the coefficients face broader intervals of acceptance for the null hypothesis, thus reducing the possibility of achieving statistical significance even more. As additional measures to verify robustness, we carried out regressions with different combinations of the CAMUL indicators and with a logarithmic transformation of the main dependent and 
independent variables, the results are very similar, but when using logarithms, the regressions very seldom pass the Sargan test (these results are not presented in tables). We also carried out regressions with the DIF GMM estimator and with fixed and flexible effects (see columns 5-7 in Tables 4 and 5). The DIF GMM estimator delivers very similar results to the SYS GMM. The regressions with fixed and flexible effects, although we know they are biased due to the fact that they cannot adequately control endogeneity, present slightly different results to the SYS GMM, but coincide by not presenting evidence in favor of the market discipline hypothesis.

Furthermore, given the fact that the sample is dominated by banks that operate in Panama, the same econometric exercises were carried out solely for these banks (not presented in tables to save space). The results obtained are qualitatively the same, unsurprisingly, since the PANAMA dichotomous variable does not present statistical significance in the regressions of the discipline price based mechanism; and, while it does present statistical significance in the quantity based mechanism, it is nothing but a reflection of the best Panamanian macroeconomic behavior.

\section{Conclusion}

The banking system is vital for the correct performance of the economy. However, several of the problems in the real sector originated in the financial sector in the last few decades. Until now, it has not been possible to foresee and prevent banking crises, a responsibility that is usually attributed to bank supervisors. Nevertheless, it is important to point out that the participants of the market also have an important role in monitoring bank risk.

According to the third pillar of Basel III, a bank policy on the disclosure of information is important for the banks to face market discipline, where the economic agents make decisions that punish banks for their risky behavior. In the case of the deposits market, it is to be expected for riskier banks to pay higher interest rates and to attract fewer funds. These hypotheses have been widely verified in the empirical literature, with evidence in favor of the market discipline hypothesis, mainly in developed countries, thus supporting the recommendations of Basel (Berger \& Turk-Ariss, 2014). The evidence in Latin American countries is mixed, and recent findings in Mexico suggest a weak presence of market discipline (Tovar-García, 2014).

Furthermore, the previous empirical results may be biased as they do not control the effect of internal demand of bank capital, just as is suggested by recent findings for the case of the United States, where by controlling said effect there is no evidence that the riskier banks pay higher interest rates. It is the banks that face a growth in loans, the ones that pay higher interest rates on deposits (Ben-David et al., n.d.).

In this research, the market discipline hypothesis was verified in the Central American banking system. Said hypothesis had already been contrasted but only for the case of Costa Rica, where the results weakly support that the riskier banks attract fewer deposits (Mayorga Martínez \& Muñoz Salas, 2002).

In this work, a sample of 30 banks in Costa Rica, El Salvador, Guatemala, Honduras, Nicaragua and Panama was used, and the 2008-2012 period was studied in the framework of the global financial crisis. Based on the SYS GMM estimator (Blundell \& Bond, 1998), there is weak evidence that the riskier banks pay higher interest rates. Specifically, it was found that the banks with the best return on assets and equity (high levels of ROA and ROE) pay lower interest rates on deposits. Consequently, it can be said that in the case of Central America there is no evidence of market discipline.

It is worth noting that the basic econometric model corrects double causality, unlike the simple models with fixed or flexible effects commonly employed in the previous literature. Furthermore, 
the main findings are robust to different indicators of bank risk (banking fundamentals), to the effect of the internal demand of bank capital, and to other estimation methods. Therefore, the main task of those in charge of banking policies is to restore market discipline, according to the recommendations of the Basel Committee, given that, except for Honduras, the rest of the Central American nations have only presented preliminary documents with regard to the implementation of the third pillar (Financial Stability Institute BIS, 2013), and in the private monitoring system elaborated by Barth, Caprio, and Levine (2013) they are classified at the lowest ranks and with negative tendencies.

This research has limitations that stem from the availability of bank data, which also exemplifies the general absence of bank information disclosure in Central America. The sample utilized in this work is dominated by banks that operate in Panama, and although panel data are used and the results are robust for different estimation methods, it would be best to be prudent when generalizing. Future researches must improve the size of the sample and extend the analysis period.

\section{References}

Arellano, M., \& Bond, S. (1991). Some tests of specification for panel data: Monte Carlo evidence and an application to employment equations. The Review of Economic Studies, 58(2), 277-297. Retrieved from http://restud.oxfordjournals.org/content/58/2/277.short

Ayadi, R. (2013). On the role of the Basel Committee, the Basel rules and banks' incentives. In G. Caprio (Ed.), Handbook of safeguarding global financial stability (pp. 403-417). Elsevier Inc. http://dx.doi.org/10.1016/B978-0-12-397875-2.00127-6

Barth, J. R., Caprio, G., \& Levine, R. (2013). Bank regulation and supervision in 180 countries from 1999 to 2011. Journal of Financial Economic Policy, 5(2), 111-219. http://dx.doi.org/10.1108/17576381311329661

Basel Committee on Banking Supervision. (2006). International convergence of capital measurement and capital standards: A revised framework comprehensive version. Retrieved from http://www.bis.org

Basel Committee on Banking Supervision. (2011). Basel III: A global regulatory framework for more resilient banks and banking systems (revised version).. Retrieved from http://www.bis.org

Basel Committee on Banking Supervision. (2014). Review of the Pillar 3 disclosure requirements. Bankfor International Settlements 2014.. Retrieved from http://www.bis.org/publ/bcbs286.pdf

Ben-David, I., Palvia, A., \& Spatt, C. (2013). Banks' internal capital markets and deposit rates. Journal of Financial and Quantitative Analysis. Retrieved from https://papers.ssrn.com/sol3/papers.cfm?abstract_id=2646840\#

Berger, A. N., \& Turk-Ariss, R. (2014). Do depositors discipline banks and did government actions during the recent crisis reduce this discipline? An international perspective. Retrieved from http://www.mooreschool.sc.edu/UserFiles/moore/Documents/Finance/Berger/DoDepositorsDisciplineBanks.pdf

Blundell, R., \& Bond, S. (1998). Initial conditions and moment restrictions in dynamic panel data models. Journal of Econometrics, 87(1), 115-143. http://dx.doi.org/10.1016/S0304-4076(98)000098

Blundell, R., Bond, S., \& Windmeijer, F. (2001). Estimation in dynamic panel data models: Improving on the performance of the standard GMM estimator. pp. 53-91. Advances in Econometrics (Vol. 15) http://dx.doi.org/10.1016/S0731-9053(00)15003-0

Bun, M. J. G., \& Windmeijer, F. (2010). The weak instrument problem of the system GMM estimator in dynamic panel data models. The Econometrics Journal, 13(1), 95-126. http://dx.doi.org/10.1111/j.1368-423X. 2009.00299.x

Cubillas, E., Fonseca, A. R., \& González, F. (2012). Banking crises and market discipline: International evidence. Journal of Banking \& Finance, 36(8), 2285-2298. http://dx.doi.org/10.1016/j.jbankfin.2012.04.011

Demirgüç-Kunt, A., \& Huizinga, H. (2004). Market discipline and deposit insurance. Journal of Monetary Economics, 51(2), 375-399. http://dx.doi.org/10.1016/j.jmoneco.2003.04.001

Financial Stability Institute BIS. (2013). FSI Survey Basel II, 2.5 and III implementation.. Retrieved from http://www.bis.org/index.htm

Flannery, M. J. (2001). The faces of market discipline. Journal of Financial Services Research, 20(2-3), 107-119. Retrieved from http://link.springer.com/article/10.1023/A:1012455806431 
Goday, V., Gruss, B., \& Ponce, J. (2005). Depositors' discipline in Uruguayan banks. Revista de Economía, 12(2), $168-204$. Retrieved from http://dialnet.unirioja.es/descarga/articulo/3184214.pdf

Hasan, I., Jackowicz, K., Kowalewski, O., \& Kozłowski, Ł. (2013). Market discipline during crisis: Evidence from bank depositors in transition countries. Journal of Banking \& Finance, 37(12), 5436-5451. http://dx.doi.org/10.1016/j.jbankfin.2013.06.007

Karas, A., Pyle, W., \& Schoors, K. (2010). How do Russian depositors discipline their banks? Evidence of a backward bending deposit supply function. Oxford Economic Papers, 62(1), 36-61. http://dx.doi.org/10.1093/oep/gpp006

Márquez, J. (2011). El seguro de depósito y su incidencia en la disciplina de mercado en Colombia. Coyuntura Económica, 41(2), 87-117. Retrieved from http://www.fedesarrollo.org.co/wp-content/ uploads/2012/08/C.-E.-Diciembre-2011-El-seguro-de-dep\%25C3\%25B3sito-y-su-incidencia-pp.-87-117.pdf

Martinez-Peria, M. S., \& Schmukler, S. L. (2001). Do depositors punish banks for bad behavior? Market discipline, deposit insurance, and banking crises. The Journal of Finance, 56(3), 1029-1051. Retrieved from http://onlinelibrary.wiley.com/doi/10.1111/0022-1082.00354/Abstract

Martínez Castillo, C. A. (2007). Basilea II, retos y oportunidades Hacia una mayor armonización de la regulación y supervisión financiera en el siglo XXI. Gestión Y Política Pública, 16(2), 465-510.

Mayorga Martínez, M., \& Muñoz Salas, E. (2002). ¿Existe disciplina de mercado en el sistema bancario costarricense? Economía Y Sociedad, (20), 61-100.

Muñoz, J. F., Cabeza, J. L., \& Guerra, W. (2013). Disciplina de mercado en la banca venezolana Período $2004-2011$. Actualidad Contable FACES, 16(27), 87-101. Retrieved from http://www.saber.ula.ve/handle/123456789/37944

Park, S. (1995). Market discipline by depositors: Evidence from reduced-form equations. The Quarterly Review of Economics and Finance, 35, 497-514. http://dx.doi.org/10.1016/1062-9769(95)90051-9

Park, S., \& Peristiani, S. (1998). Market discipline by thrift depositors. Journal of Money Credit and Banking, 30(3), 347-364. Retrieved from http://www.jstor.org/stable/10.2307/2601105

Ríos, B. (2012). Ranking bancos: El oxígeno de la banca global. Mercados \& Tendencias, 32-59. Retrieved from http://revistamyt.com/wp-content/uploads/2012/07/ranking-de-bancos-2012.pdf

Sarkar, A., Bhole, L. M., Sarkar, A., \& Bhole, L. M. (2009). Bank depositors' role as a disciplinary force in Indian banking: A dynamic panel approach. In R. P. Padran (Ed.), Forecasting financial markets in India (pp. 30-39). India: Allied Publishers Private Limited. Retrieved from https://books.google.com.mx/books?id= D_8eoSMaD8cC\&pg=PA1 18\&lpg=PA118\&dq=\%22Forecasting+Financial+Markets+in+India $\% 22 \&$ source $=$ bl $\&$ ots=nrP7Awq2Dr\&sig=QfPAqCln3hRDQiETcTR3XapOEdA\&hl=en\&sa=X\&ved=0ahUKEwj49OO80tTSAhUX5 GMKHbxPCQMQ6AEIIzAC\#v=onepage \&q=Sarkar\&f=fal

Sulamita Estrada, Y. (2013). El fondo de seguro de depósito en la estabilidad financiera en Centroamérica República Dominicana y Panamá. Notas Económicas Regionales, (64), 1-11.

Tovar-García, E. D. (2012). Market discipline in Mexican banks: Evidence from the asset side Cuadernos de Economía. Spanish Journal of Economics and Finance, 35(99), 172-181. http://dx.doi.org/10.1016/S0210-0266(12)70033-X

Tovar-García, E. D. (2014). Market discipline: A review of the Mexican deposit market. Latin American Economic Review, 23(6), 1-33. http://dx.doi.org/10.1007/s40503-014-0006-2

Tovar-García, E. D. (2015). Market discipline through subordinated debt in mexican banks. Revista de Economia Aplicada, 23(68), 61-80.

Tovar-García, E. D. (2016a). Exposure to interbank market and risk-taking by Mexican banks. Cuadernos de Economía. Spanish Journal of Economics and Finance, 39(111), 157-174. http://dx.doi.org/10.1016/j.cesjef.2015.11.002

Tovar-García, E. D. (2016b). Who can better monitor a bank than another bank? Mechanisms of discipline in the Mexican interbank market. Revista de Métodos Cuantitativos Para La Economía Y La Empresa, 21(1), 205-229. Retrieved from http://www.upo.es/RevMetCuant/art.php?id=123

Tovar-García, E. D., \& Kozubekova, R. (2016). The third pillar of the Basel accord: Evidence of borrower discipline in the Kyrgyz banking system. Journal of Eurasian Studies, 7(2), 195-204. http://dx.doi.org/10.1016/j.euras.2016.02.002

Windmeijer, F. (2005). A finite sample correction for the variance of linear efficient two-step GMM estimators. Journal of Econometrics, (126), 25-51. http://dx.doi.org/10.1016/j.jeconom.2004.02.005

Wu, Y., \& Bowe, M. (2012). Information disclosure and depositor discipline in the Chinese banking sector, Journal of International Financial Markets. Institutions and Money, 22(4), 855-878. http://dx.doi.org/10.1016/j.intfin.2012.05.004 